\title{
SYSTEMATIC STUDY TOWARDS HIGH EFFICIENCY MULTICRYSTALLINE SILICON SOLAR CELLS WITH MECHANICAL SURFACE TEXTURIZATION
}

\author{
C. Zechner, G.Hahn, W. Jooss, M. Wibral, B. Bitnar, S. Keller, M. Spiegel, P. Fath, G. Willeke, E. Bucher, \\ University of Konstanz, Faculty of Physics, P. O. Box 5560, D-78457 Konstanz, Germany
}

\begin{abstract}
The aim of the present work was to optimize a high efficiency process for multicrystalline silicon solar cells (including Al-gettering, oxide and hydrogen passivation, Al-BSF formation, photolithographically defined front metallization) and combine it with the mechanical texturization technique. New cell structures were created, in which only the areas between the front grid are Vgrooved. Solar cells were processed on various ribbon and conventional cast silicon materials. IV-characteristics, reflectance and spectral response were measured and analysed by two dimensional device simulation. A comparison with equally processed flat cells shows an increase of cell efficiencies by more than $25 \%$ due to the reduction of optical losses before antireflection coating and by additional $4 \%$ due to the enhanced collection probability in the $\mathrm{V}$-groove volumes.
\end{abstract}

\section{INTRODUCTION}

In the past few years mechanical surface texturization has been shown to be a powerful technique to improve solar cell efficiency $[1,2]$. It reduces the reflection losses, yields a good light-trapping for long wavelength photons and increases the collection probability of minority carriers generated in the base by providing a larger collection surface [3]. Mechanical structuring is particularly useful for multicrystalline substrates, where anisotropic etching is rather ineffective due to the random distribution of the crystal grain orientations.

The main purpose of the present work is to determine the benefit of this surface texturization method as a part of high efficiency solar cell processes on multicrystalline substrates.

Conventional formation of high quality front contacts is usually more difficult on mechanicaliy structured surfaces than on flat surfaces. E.g. screen printed contacts perpendicular to the $\mathrm{V}$-grooves can be interrupted on the top of the V-grooves [2]. Photolithography is more difficult, because the photoresist thickness is not uniformly distributed over a V-groove due to capillary effects. As further alternatives shallow angle metallization techniques $[4,5]$ are highly adapted concepts to metallize macroscopically V-textured wafers for high efficiency solar cells. V-texturization can also be integrated in the buried contact solar cell process [6].

In order to create similar front contacts for textured and untextured cells, we implemented two new cell structures, in which most of the front surface is mechanically V-grooved, while the contact areas are untextured. The metal fingers are made either parallel to the V-grooves on unstructured areas, or perpendicular on deep, flat grooves. The textures were created by using a conventional dicing saw on which either a single beveled blade or a structuring wheel was mounted.

High efficiency solar cells with these new structures have been fabricated at the University of Konstanz and are compared to equally processed flat cells. The effects of $P$ and $\mathrm{Al}$ gettering as well as of oxide and hydrogen passivation were investigated. Polycrystalline materials (Bayer RGS (Ribbon Growth on Substrate), Bayer Soplin, EMC, Eurosolare Eurosil, Solarex multi Si) of small $(<20 \mu \mathrm{m})$ and large $(>150 \mu \mathrm{m})$ starting diffusion lengths were used.

The obtained currents and energy conversion efficiencies were considerably higher on textured cells than on the flat reference cells, due to lower reflection losses and increased long wavelength quantum efficiency. The beneficial effects of the V-texture were further analysed by two-dimensional optical and electrical device simulations.

\section{SOLAR CELL PROCESS}

The effects of several techniques which are described as beneficial for mc-silicon solar cells in the literature were studied by integrating them into standard solar cell processes that involve the following steps:

1) $\mathrm{POCl}_{3}$ emitter diffusion ( $80 \Omega / \mathrm{sq}$.)

2) Dry thermal oxidation at $900^{\circ} \mathrm{C}$

3) Al evaporation at the back side and sintering

4) Evaporation of photolithographically defined $\mathrm{Ti} / \mathrm{Pd} / \mathrm{Ag}$ front contacts + lift-off

5) Al evaporation of back contact and sintering

On some cells a $\mathrm{SiN}_{x} / \mathrm{SiO}_{2}$ double antireflection coating (DARC) was deposited. The influence of the Al gettering temperature on the solar cell performance was studied in detail for various mc-Si materials. The results are given in [7]. In the following we report on the integration of a microwave induced remote hydrogen plasma (MIRHP) 
treatment and a phosphorus pregettering step into our high efficiency process.

\section{Hydrogen passivation}

The benefit of a MIRHP treatment $[8,9,10,11]$ after the cell metallization was investigated for various $\mathrm{mc}-\mathrm{Si}$ materials (EMC, Solarex, RGS, Bayer Soplin, Eurosolare, Photowatt) [7]. We found, that it generally increases the bulk diffusion length, while the emitter and front surface quality tend to decrease during the MIRHP treatment (see Fig. 1). In cells with a homogeneous emitter, most mc-Si materials showed only modest improvements in the cell characteristics. MIRHP was found to be particularly effective for EMC Si, for Bayer RGS Si and for one type of Solarex mc-Si with small starting diffusion lengths. For these three materials, a raise in $\mathrm{V}_{o c}$ in the range of $30 \mathrm{mV}$ due to the MIRHP passivation was observed, which was accompanied by a considerable increase in the bulk diffusion length.

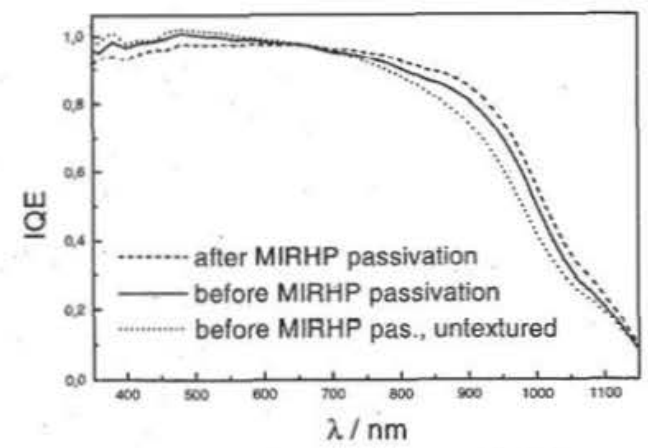

Fig. 1. Internal quantum efficiency of a V-textured Eurosil mc-Si solar cell before and after a 70 min MIRHP treatment and a untextured reference cell taken from a neighboring wafer with the same crystal grains.

\section{Phosphorus pregettering}

$P$ pregettering treatments were reported to significantly increase the bulk lifetime $\tau_{B}$ in Eurosil and Bayer Soplin mc-Si wafers $[12,13]$. In the present work we studied the effect of P-pregettering on Eurosil material by applying an additional P-diffusion and removing a $3 \mu \mathrm{m}$ layer from both surfaces after this step. We investigated getter temperatures between $820^{\circ} \mathrm{C}$ and $950^{\circ} \mathrm{C}$, different gettering times and applied processes with and without thermal oxidation, using $5^{\star} 5 \mathrm{~cm}^{2}$ wafers of neighboring ingot positions and processing four $22^{\star} 2 \mathrm{~cm}^{2}$ solar cells on each wafer. A comparison of the influence of pregettering on the solar cell performance $\left(V_{\infty}, J_{s c}, F F, \eta\right)$ between cells with the same crystal grain structure did not show a uniform behavior for the four sets of corresponding $2^{\star} 2 \mathrm{~cm}^{2}$ cells. In average, the solar cells processed on reference wafers without pregettering treatment showed a somewhat better performance than the pregettered cells. In order to clarify the observed behavior further investigations on P-gettering will be made, in which spatially resolved lifetime monitoring will be carried out.

\section{MECHANICAL TEXTURIZATION}

The implemented mechanically texturized structures are shown in Fig. 2 and Fig. 3. Analogous structures were already created earlier by anisotropic etching of monocrystalline silicon, resulting in the first silicon solar cell to exceed $20 \%$ energy conversion efficiency at 1 -sun illumination [14]. Obviously, the sheet resistance losses are smaller in structure B.

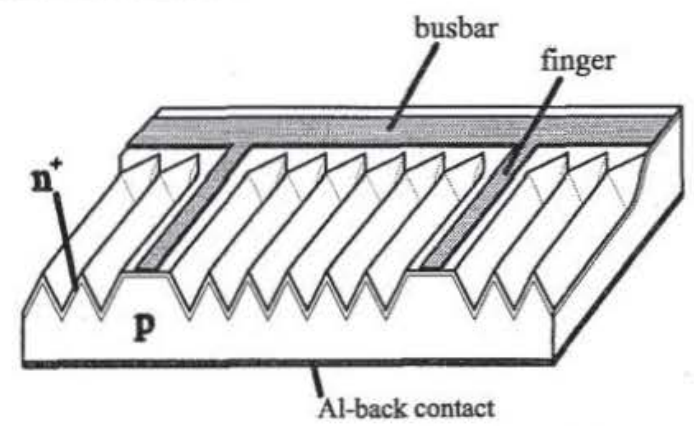

Fig. 2. High efficiency structure A with grid fingers parallel to deep V-grooves

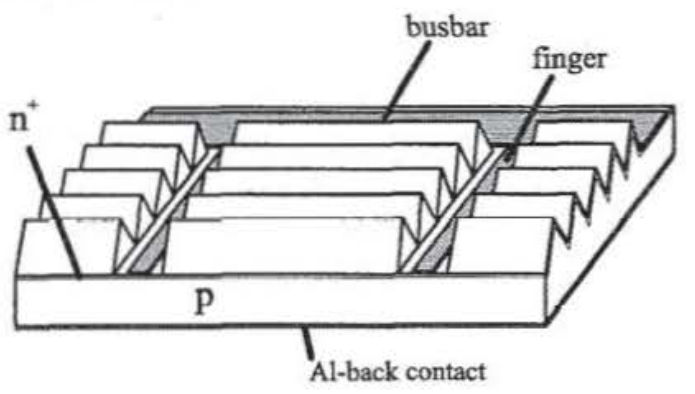

Fig. 3. High efficiency structure B with grid fingers perpendicular to deep V-grooves. The deep, flat grooves for the fingers are created in an additional sawing step.

We calculated the absolute FF-losses due to the sheet resistance to $0.8 \%$ and $0.2 \%$ for structure $A$ and $B$, respectively, for $80 \Omega / \mathrm{sq}$. emitters. However, structure A seems to be very promising for industrial applications for it is suited for screen printing metallization and optimally suited for the low-cost roller printing metallization technique [15], where only the high-lying contact areas are metallized, whereas the lower V-groove regions are not. The grooves were formed with a conventional mechanical dicing saw with beveled as well as flat blades. For some cells of structure B the V-grooves were formed using a structuring wheel [16], thereby reducing the number of necessary cutting steps for the V-texturing to two cuts per wafer.

Most of the mc-Si materials used did not show breakage problems due to mechanical texturization. An exception was a $200 \mu \mathrm{m}$ thick cast mc-Si material of one supplier that contained visible nitride and carbide precipitates.

Since photolithography turned out to be difficult on deep structures we chose a groove depth of $60 \mu \mathrm{m}$ for all Vgrooves in the present work. 


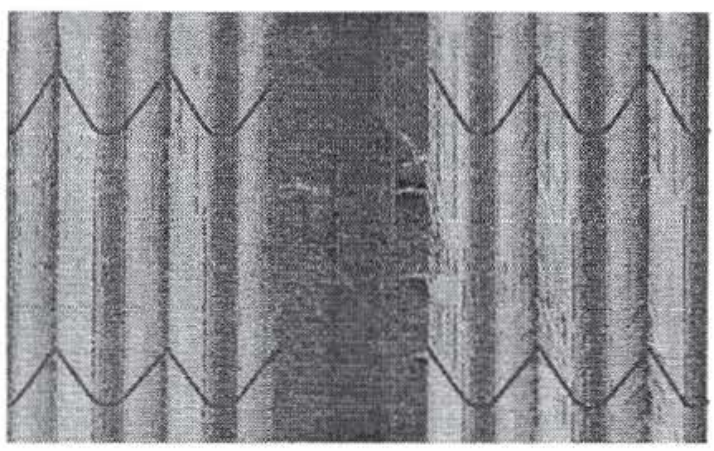

Fig. 4. Scanning electron micrograph of a photolithographically defined metal finger (dark stripe in the middle of the unstructured area) on an RGS solar cell of structure A. The grey lines are inserted by hand as a guideline to the eyes.

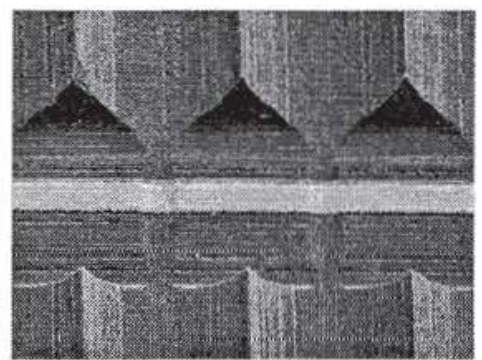

Fig. 5. Scanning electron micrograph of a photolithographically defined metal finger on a mc-Si solar cell of structure $\mathrm{B}$, textured with a structuring wheel. The flat groove width was $150 \mu \mathrm{m}$ in order to enable high quality photolithography.

\section{RESULTS}

\section{Comparison of textured and flat cells}

The major advantage of texturization is the reduction of reflection losses. In this respect, single blade structured cells perform better than cells which are structured with texturization wheels, due to the more ideal groove shape (see Fig. 6). However, if the cell is encapsulated into a module, large V-tip angles as obtained by using a structuring wheel provide a very low reflection, too, because of the light trapping action of the encapsulant [17]. In [18] reflectances for several mechanical textures with anti reflection coating and encapsulation are presented, which are calculated with the silicon solar cell optics program SONNE [19].

Another advantage of mechanically textured cells is the increased long wavelength quantum efficiency due to the high minority charge carrier collection probability inside the V-tip volume [3]. In the present work the internal quantum efficiency (IQE) was measured on textured and untextured cells that had been processed in the same batch (see Fig. 7). The results for long wavelength illumination were fitted by IQE-curves which were calculated by two dimensional device simulation based on the commercially available device simulator DESSIS [20] and the silicon solar cell optics program SONNE [19], as described in [21]. Comparing the results measured on the same crystal grains of neighbored wafers, we found that the higher IQE of textured cells is a pure geometry effect, while the diffusion length is not altered by the texturization.

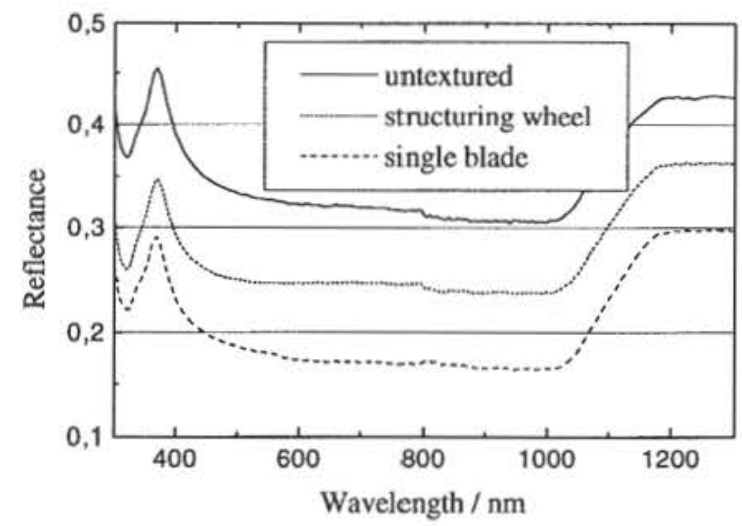

Fig. 6. Measured hemispherical reflectance of a 'structure A'-solar cell with $60 \mu \mathrm{m}$ deep V-grooves, a 'structure B' solar cell that was textured with a structuring wheel and a flat solar cell. All cells were processed in the same batch and measured without ARC.

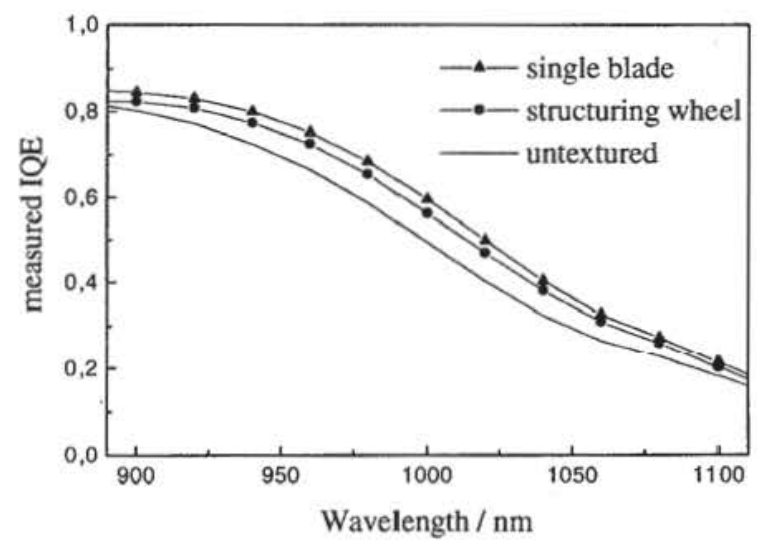

Fig. 7. Measured long wavelength internal quantum efficiency (IQE) of equivalent solar cells with different surface textures. All three cells have a bulk diffusion length of about $140 \mu \mathrm{m}$.

Table 1 shows the results of a comparison between 12 single blade structured cells on cast mc-Si material and 12 flat reference cells before antireflection coating. The boost in short circuit current $\left(\mathrm{J}_{\mathrm{sc}}\right)$ was $35 \%$ relative in average as compared to the flat cells. This is mainly due to the reduction of reflection losses, which can be seen from reflectance measurements. However, on average $1 \mathrm{~mA} / \mathrm{cm}^{2}$ of the current gain was due to the enhanced collection probability inside the $\mathrm{V}$-tip-volume. This value was calculated by an analysis of the reflectance curves of all structured cells and confirmed by spectral response measurements and by two dimensional computer simulations. 
Table 1. Comparison of 12 'structure A'-solar cells to 12 equally processed flat solar cells. (The two best cells were at equivalent places on neighboring wafers.) All cells are without MIRHP-passivation and without ARC.

\begin{tabular}{|c|c|c|c|c|}
\hline & $\begin{array}{c}J_{s c} \\
{\left[\mathrm{~mA} / \mathrm{cm}^{2}\right]}\end{array}$ & $\begin{array}{c}\mathrm{V}_{\text {oc }} \\
{[\mathrm{mV}]}\end{array}$ & $\begin{array}{c}\mathrm{FF} \\
{[\%]}\end{array}$ & $\begin{array}{c}\eta \\
{[\%]}\end{array}$ \\
\hline $\begin{array}{c}\text { best cell of } \\
\text { structure A }\end{array}$ & 30.45 & 603.8 & 76.9 & 14.13 \\
\hline $\begin{array}{c}\text { best untextured } \\
\text { cell }\end{array}$ & 23.05 & 596.9 & 76.9 & 10.59 \\
\hline $\begin{array}{c}\text { average gain } \\
\text { by struct. A } \\
\text { (all 12 cells) }\end{array}$ & $\begin{array}{c}+7.6 \\
\pm 0.4\end{array}$ & $\begin{array}{c}-1 \\
\pm 9\end{array}$ & $\begin{array}{c}-0.5 \\
\pm 1\end{array}$ & $\begin{array}{c}+3.2 \\
\pm 0.2\end{array}$ \\
\hline
\end{tabular}

Ideally, the increase of $J_{s c}$ in the cells of structure $A$ should be accompanied by a raise of $V_{o c}$ of about $8 \mathrm{mV}$. On average, no $\mathrm{V}_{\text {oc }}$ raise was observed. Computer simulations show that this can be ascribed to the increased carrier injection into the base from the larger emitter area.

\section{High efficiency solar cells}

Using Eurosil cast mc-Si and RGS Si, we processed high efficiency solar cells of structure $A$ and applied a MIRHP passivation after the cell metallization. Table 2 shows the cell results for the best cells of both materials. Both cells were processed with a fully metallized back side and without $P$ pregettering. The evaporated front grid was not thickened by electroplating and only $3 \mu \mathrm{m}$ thick. The grid shading losses are about $3 \%$, and the fill factor losses due to ohmic resistance in the grid were calculated to about $2.5 \%$ absolute. The efficiency reached on the RGS cell is the highest ever reported for this material.

Table 2. IV-data of the best RGS and Eurosil cells of structure A before MIRHP passivation (bef. H), after MIRHP passivation (aft. H) and after double layer ARC depostion (ARC). The results shown in the third row have been certified by the Fraunhofer ISE in Freiburg, Germany. Ref ${ }_{\mathrm{av}}$ is the weighted average of the reflection in the wavelength region between $350 \mathrm{~nm}$ and $1000 \mathrm{~nm}$.

\begin{tabular}{|c|c|c|c|c|c|c|}
\hline Material & time & $\begin{array}{c}\mathrm{Ref}_{\mathrm{av}} \\
{[\%]}\end{array}$ & $\begin{array}{c}\mathrm{J}_{\mathrm{sc}} \\
{\left[\mathrm{mA} \mathrm{cm}^{2}\right]}\end{array}$ & $\begin{array}{c}\mathrm{V}_{\mathrm{oc}} \\
{[\mathrm{mV}]}\end{array}$ & $\begin{array}{c}\mathrm{FF} \\
{[\%]}\end{array}$ & $\begin{array}{c}\eta \\
{[\%]}\end{array}$ \\
\hline RGS & bef. H & 16.2 & 22.9 & 511 & 72.2 & 8.5 \\
\hline RGS & aft. H & 16.2 & 25.7 & 538 & 74.6 & 10.3 \\
\hline RGS & ARC & 5.0 & 28.5 & 538 & 72.4 & 11.1 \\
\hline Eurosil & bef. H & 18.4 & 30.2 & 603 & 76.9 & 14.0 \\
\hline Eurosil & aft. H & 18.4 & 30.5 & 605 & 77.6 & 14.3 \\
\hline
\end{tabular}

\section{CONCLUSIONS}

The overall benefit of mechanical texturization as a first step of high efficiency cell processes for multicrystalline silicon was investigated. For that purpose two new front surface structures have been implemented, which enabled high quality front contacts and an accurate comparison to reference cells without mechanical texturization.
Tetxured solar cells on Eurosolare multicrystalline wafers with the presented front surface structures showed short circuit current density increases of $35 \%$ on average as compared to flat cells before antireflection coating. Solar cells on Bayer RGS wafers reached the highest energy conversion efficiencies ever reported for this material.

\section{ACKNOWLEDGEMENTS}

We like to thank M. Keil for technical assistance during solar cell processing. This work was supported by the German BMBF under contract number 0329557A and within the JOULE program of the European Commission under contract number JOR3-CT95-0030.

\section{REFERENCES}

[1] H.Nakaya et al., Sol. En. Mat. and Solar Cells 34, 1994, pp. 219-225

[2] J.Szlufcik et al., 12 th ECPVSEC, 1994, pp. 769-772

[3] C.Zechner et al., "Numerical Simulation Studios of Mechanically Textured High Efficiency Silicon Solar Cells", $14^{\text {th }}$ ECPVSEC, Barcelona 1997, in print

[4] B.Terheiden et al., "LOPE (LOcal Point contact and shallow angle Evaporation) silicon solar cells", in ref. [3]

[5] R. Hezel, $13^{\text {th }}$ ECPVSEC, 1995, pp. 115-118

[6] R.Kühn et al., "Multicrystalline buried contact solar cells using a new electroless plating metallization sequence and a high througput mechanical groove formation", in ref. [3]

[7] G.Hahn et al., "Improvement of mc Si solar cells by Algettering and hydrogen passivation ${ }^{\alpha}$, this conference

[8] Elgamel et al., J. Appl. Phys. 78, 1995, pp. 3457-3461

[9] R.Lüdemann et al., "Evaluation of Different Hydrogen Passivation Methods", in ref. [3]

[10] M.Spiegel et al., $13^{\text {th }}$ ECPVSEC, 1995, pp. 421-424

[11] M.Spiegel et al., "Microwave induced remote hydrogen plasma (MIRHP) passivation of solar cells using different silicon base materials", in ref. [3]

[12] M.Stocks et al., "Minority carrier lifetimes of multicrystalline silicon during solar cell processing", in ref. [3]

[13] A.El Moussaoui et al., "Influence of temperature in a simple Si solar cell fabrication process", in ref. [3]

[14] A.W.Blakers, M.A.Green, "20\% Efficiency Silicon Solar Cells", Appl. Phys. Lett.. 48, 1986, pp.215-217

[15] P.Fath et al., $13^{\text {th }}$ ECPVSEC, 1995, pp. 29-32

[16] P.Fath et al., Tech. Dig. of the Internat. PVSEC-9, Miyazaki, Japan, 1996, pp. 107-108

[17] R.Brendel, Prog. In Photovolt. 3, 1995, pp. 25-38

[18] C.Gerhards et al., " Mechanically V-textured low cost multicrystalline silicon solar cells with a novel printing metallization", this conference

[19] C.Zechner et al., "Two and three dimensional optical carrier generation determination in crystalline silicon solar cells", Sol. En. Mat. and Solar Cells, in print

[20] Reference Manuals, ISE AG, Zurich, 1997

[21] S.Keller et al., "Quantum efficiency simulation and analysis of crystalline silicon solar cells by two dimensional device simulation", in ref. [3] 